Nord, Lars $W$. Newspaper competition and content diversity: a comparison of regional media markets in Sweden.

\title{
NEWSPAPER COMPETITION AND CONTENT DIVERSITY. A COMPARISON OF REGIONAL MEDIA MARKETS IN SWEDEN
}

\section{COMPETITIVIDAD ENTRE DIARIOS Y LA DIVERSIDAD DE SUS CONTENIDOS. UN ANÁLISIS COMPARADO EN LOS MERCADOS REGIONALES DE LOS MEDIOS IMPRESOS EN SUECIA}

\author{
LARS W. NORD \\ Professor in Political Communication \\ Director, Centre for Study of Democracy and Communication \\ Mid Sweden University \\ lars.nord@miun.se
}

Fecha de recepción: marzo de 2013

Fecha de aceptación: mayo de 2013

\begin{abstract}
.
This article discusses the relationship between the newspaper market structure in a region and the diversity of local news. It introduces some partial results on studies based on substantial media concentration within two very different regional newspaper markets in the North and in the South of Sweden. The findings suggest that the relationship between newspaper competition and local news diversity is rather complicated. The study gives some support to the thought that ruinous competition sometimes could be as bad for news diversity as monopoly media.
\end{abstract}

\section{KEYWORDS.}

Content diversity, competition, monopoly, newspaper market, democracy

\section{RESUMEN.}

Este artículo trata sobre la relación entre la estructura de mercado regional para los periódicos impresos y la diversidad de las noticias locales. Presenta los resultados parciales de algunos estudios basados en la concentración de medios impresos en dos mercados regionales muy diferentes en el Norte y el Sur de Suecia. Los hallazgos sugieren que la relación entre la competencia entre los diarios y la diversidad de las noticias locales es más bien compleja. El estudio sustenta, asimismo, la idea de que la competencia destructiva en ocasiones puede ser tan negativa para la diversidad en la información como los mercados monopolísticos.

PALABRAS CLAVE.

Diversidad de contenido, competencia, monopolio, mercado de periódicos, democracia.

JEL: D40, L82. 
Nord, Lars $W$. Newspaper competition and content diversity: a comparison of regional media markets in Sweden.

\section{INTRODUCTION}

Newspapers undoubtedly form a part of the democratic process even if it is sometimes unclear exactly how. Sweden actually adheres to this scenario. When confronted with the death of a traditional and politically important newspaper, such as with Arbetet in Malmö some years ago, the public debate was focused on the loss of diversity as a result of decreased newspaper competition in their region. However, when faced with the introduction of newcomers to the market, such as the free tabloids Metro or Stockholm City in Stockholm, the same worries were expressed, but now based on the assumption that increased competition will be a threat to diversity and "the marketplace of ideas".

Thus, the relationship between newspaper competition and the quality of democracy in terms of a free press seems to be rather confusing and worth further analysis. One argument supporting the contradictory statements cited above could be that newspapers actually differ, and while some contribute to democratic values others do not. Therefore, a newspaper with a long publishing tradition and a strong party affiliation such as Arbetet was looked upon somewhat differently to the free tabloids, which were distributed in the underground system. Nevertheless, such an explanation could be disputed for democratic reasons. The audience for the metropolitan papers is certainly much bigger than for a second-ranking regional party-press paper. Current empirical studies in Sweden also show that the free tabloids fill a media void in suburban areas and reach people who would normally not read a daily newspaper at all (Wadbring, 2003; Nygren, 2005). At the same time, even the death of one newspaper in a region still usually offers people access to another paper.

The objective of this article is to examine the relationship between regional newspaper market structures and local news quality in terms of diversity and objectivity. The first part of the article discusses some theories in the field and empirical findings in international research. The last part presents two case studies based on the regional newspaper market in Sweden where news content in different market situations are compared and the implications for free press ideals are discussed. Unfortunately, there has been little research in Sweden in this field so the empirical data presented here is discussed within the international theoretical framework.

\section{LITERATURE REVIEW}

Historically, main theories about the benefits of newspaper competition originate from a liberal media theory, where the media market works in the same way as any other market (Keane, 1991). According to the libertarian theory of the press, the effectiveness of a news medium depends upon its performance as a "free marketplace of ideas" (Lasorsa, 1991). Rivalry between entrepreneurs yields the best quality for products and services, as well as offering the lowest possible prices.

\subsection{The virtuous circle of competition}

If this marketplace of news and opinions - with free and equal access for all people is left without interference from the government it will also - according to liberal 
Nord, Lars $W$. Newspaper competition and content diversity: a comparison of regional media markets in Sweden.

theory - produce the kind of information people need. Newspaper organizations need to sell copies to attract readers and advertisers, and they also need to be profitable in order to satisfy their owners (Hamilton, 2004). From a liberal media viewpoint, newspapers need to compete against each other about news, audiences, advertisers and capital (McManus, 1994). Competition is necessary to bring better products and in the 'perfect' market the fittest will survive: namely those newspapers in greatest demand in the market. If less successful competitors have to leave the market this is not a huge disadvantage, as the market does not demand their product. Competition is not only considered to be a guarantee of quality of products, but also the agent of innovation and pluralism in society (Page, 1996; Doyle, 2002).

The main other normative theory about media and democracy is the social responsibility theory (Siebert et al. 1956; Hallin \& Mancini, 2004). In contrast to liberal theory, this theory recognizes the problem of market imperfections. Thus, it argues for an active media policy to balance imperfections and guarantee media diversity. The social theory does however have one thing in common with liberal theory as both assume the need for media competition as a mean to achieve different objectives. In liberal theory, the main objective is the perfect allocation of resources on the market (capitalism) and in social responsibility theory the main objective is the perfect allocation of ideas on the market (pluralism).

The most interesting conclusion in this context is perhaps that the benefits of media competition are more or less taken for granted in quite different media theories. It is also an undisputed truth in daily politics where politicians from both the left and right repeatedly confess their beliefs in increased media competition and the democratic risks for media monopolies. How could there be "a marketplace of ideas" if only one seller exists behind the counter?

The idea of the effects of newspaper competition is, in the main, based on economic demand theory. When competition increases in a media market it pushes the competing companies into financial commitments to increase content diversity and attract more readers (Litman \& Bridges, 1986). Where there is competition, journalists need to do their best to report all newsworthy events in an accurate way (Bird, 1940). The idea behind this argument is that a newspaper wants to be perceived both as a substitute for its rivals and something more than its rivals by producing "exclusive" news stories (Lasorsa, 1991).

According to a comprehensive model of this process, introduced by Lacy, there are at least four steps from competition to market performance. The main strength in Lacy's model is the central role of financial commitment to increase news quality if competition intensifies. This first step in his model has also been supported in most studies of the relationship between media competition and financial commitment to the newsroom. Intense competition between newspapers increased their use of national wire services, the amount of local news coverage and colour and graphics on news pages. Lacy presented strong evidence that the content of newspapers in a competitive market is more extensive than similar newspapers in a monopoly market (Lacy, 1987). In another study of local election coverage in media markets in the US, Vermeer found that the presence of more newspapers in an area led to closer outcomes in races for the US Senate and for governor (Vermeer, 1995). 
Nord, Lars $W$. Newspaper competition and content diversity: a comparison of regional media markets in Sweden.

The second step in Lacy's model, examining the relation between financial commitment and content quality, has not been investigated as thoroughly as the first step, but the few studies which have been conducted support the hypothesis and argue that there is a relationship between newsroom resource allocations and balanced reporting. The third and fourth steps, examining effects on readers' utility and use of the product, have not been examined (Lacy, 2000).

The financial commitment model can be disputed in many ways, and Lacy also admits that its validity depends on how efficiently the process turns additional funds into improved quality. He argues that financial commitments depend both on profit margins in media firms and possible conflicts between newsroom investments, and on stock market considerations (Lacy, ibid.). McManus further develops the last point in his work about market-driven journalism at local TV news stations. He argues that market logic's domination of journalistic logic is almost complete and that strategies for maximizing returns to investors are the single most important goal for commercial media firms (McManus, 1994). Thus, there are also obvious limitations for unconditional financial commitments to newsrooms when market competition increases due to conflicting corporative goals concerning news markets and capital markets.

\subsection{The vicious circle of competition}

The thesis about the unconditional benefits of media competition is controversial among media scholars. van Cuilenberg notes that media competition might sometimes degenerate into ruinous competition and he raises the interesting question about whether there is an optimal point in media markets where media diversity is promoted between two extreme positions: media monopoly and ruinous competition (van Cuilenberg, 2000). The latter situation is sometimes characterized as "too many products, too much fake diversity" (Baker, 2002).

van Cuilenberg examines both Dutch newspaper markets and European television markets and he concludes that media oligopolies seem to encourage a certain aspect of media quality, namely media diversity. He finds no support for the popular theory about a relationship between ownership concentration and editorial concentration. On the contrary, his press barometer for the Netherlands shows that mergers and take-overs in fact weaken the effects of economic and social market forces that lead to editorial concentration and the exit of newspaper titles from the market (van Cuilenberg, 2000).

Entman draws the conclusion that there is a central contradiction between the logic of the media market and the logic of the marketplace of ideas. In many ways they oppose the liberal theory of media competition by arguing that the economic imperatives of downsizing costs and maximizing profits both affect newsgathering procedures and newspaper content. Entman refers to a growing uncertainty among academic scholars about the relationship between newspaper company structure and the metaphorical marketplace of ideas. According to Entman this relation is very difficult to predict and depends on a number of forces, as for example tastes among audiences, competitive strategies of newspapers, the desires of advertisers and owners valuation of political influence and profit (Entman, 1989). 
Nord, Lars $W$. Newspaper competition and content diversity: a comparison of regional media markets in Sweden.

Entman infers that newspaper competition could stimulate both better and worse newspaper content, as there are differing demands from readers, advertisers, owners and sources. Sometimes the market situation stimulates competition with more local news, investigative reporting and public debate platforms, but sometimes the market situation stimulates less high-quality journalism and more infotainment, trivialization and soft formats in order to attract the biggest possible audience. At the same time, some monopoly newspapers succeed in guaranteeing intra medium diversity and dare to challenge big interests in society, while others gather lazy staffs and produce poor quality news as a result of lack of competitors. There are even some examples where newspapers in a new monopoly situation expand their editorial staff (Baker, 2002). Thus, newspaper quality cannot be predicted only from a competition perspective.

Entman refers to media content analysis among ninety American newspapers in the 1970's where newspaper competition did not influence the existence of seriousness, diversity, balance and responsiveness in news. Thus, Entman concludes that it is not the degree of newspaper competition that most directly shapes news quality, but the priorities of the publisher and the specific preferences among audiences and advertisers (Entman, 1989). In another American study 423 journalists were asked about their perceptions regarding how newspaper competition affects content. Once again, there were mixed emotions about competition as most journalists believed competition promoted editorial diversity and competitiveness among journalists, but at the same time, also increased sensationalism in news reporting. This study was followed up by a new study in 1997 where journalists and editors were asked about newspaper competition and its influence on City Hall reporting. The results showed that this competition could have positive and negative effects. The amount of coverage of local politics increased in competitive markets, but at the same time indepths stories decreased, especially in smaller papers (Lacy, Coulson \& St. Cyr, 1999).

To sum up, there are contradictory democratic arguments for and against newspaper competition. The positive arguments focus on the effects on media diversity, quality and the public interest of internal and external pluralism. At the same time, the negative arguments emphasize the risks for a limited, or even belligerent competition, favouring mainstream positions and low-quality journalism (Meier \& Trappel, 1998). However, empirical evidences of such effects remain unclear. Where there is evidence, the effects seem to be quite small (McQuail, 1998).

\section{MEDIA MARKETS AND DEMOCRACY}

Previous studies do to some extent confirm the positive effects of competition on news diversity; however at the same time there are other results indicating negative influences as the news becomes more mainstream or sensationalized due to a ruinous competition. The relationship between market structure and news diversity then seems to depend on more factors than only the number of competitors in the market. Therefore a more comprehensive model of this relationship should at least try to identify differing quality standards in different market situations (fig.1). 
Nord, Lars $W$. Newspaper competition and content diversity: a comparison of regional media markets in Sweden.

Figure 1. Typology of Market Structures

\begin{tabular}{|l|c|c|}
\hline \multicolumn{1}{|c|}{ Competition: } & No & Yes \\
Efficiency: & & Free Market \\
\hline Yes & Oligopoly & Ruinous Competition \\
\hline No & Monopoly &
\end{tabular}

Source: Own elaboration.

The economic textbook versions of this topic often focus on the difference between monopoly and the free market, where it is the latter that has much greater opportunities to meet the demands from the audience, the advertisers and the public good. This argument is the cornerstone in both liberal and social responsibility media theories. In reality, however, the choice is most often not between a total monopoly situation and a perfect market model, but between one not-so-perfect combination of quality and competition and another not-so-perfect combination. In economic literature these cases are often described as "theories of the second best". The oligopoly could work better than expected due to market sharing and successful product differentiation, while competition might sometimes degenerate.

Previous research confirms that both competitive and non-competitive newspaper markets differ in news diversity. Thus, studies focusing on only the competition situation risk missing the point. It may be more useful to examine why noncompetitive markets sometimes develop accurate reporting and competitive markets sometimes turns into an arena of ruinous competition with more trivial and mainstream news.

Instead of focusing only on the number of media organizations in the market it is surely of great interest to know how each media organization is operated when it comes to owner ideology, professional values, market-driven journalism and audience perceptions (Shoemaker \& Reese, 1996). A media organization where owners use profits for journalistic improvements and ambitions to reflect opinion diversity offer rather different democratic contributions to the market than do media organizations where pay offs to investors through mainstream or down-market journalism are given the highest priority. Journalistic ambitions can thus sometimes be higher in an oligopoly situation where the market is shared and resources are allocated in a more efficient way compared to a ruinous competition situation.

There is no doubt that competition does indeed matters for diversity, but so also do internal factors within media organizations and media relations to other actors such as audiences and advertisers. The main point in this argument is that changes in newspaper competition are not the only things affecting changes in news diversity. From a democratic perspective it is unnecessary to rely only on economic market models for evaluating media performances. On the contrary, lost competition could under certain circumstances sometimes lead to unchanged, or even improved, news diversity. It is also possible to identify market changes where new competition in a former oligopoly market results in aggressive or populist journalism with reduced local news diversity. There are therefore reasons to reconsider the benefits of newspaper competition for democracy and pluralism. News diversity is certainly a more valid concept for evaluating media contributions to democracy and freedom of speech. Thus, the quality of democracy could be obtained both in non-competitive media markets and in markets characterized by intense competition. 
Nord, Lars $W$. Newspaper competition and content diversity: a comparison of regional media markets in Sweden.

\section{RESEARCH QUESTION AND DEFINITIONS}

The objective of this article is to examine and discuss the relationship between the newspaper market structure in a region and the diversity of local news reporting by examining two different Swedish regional media markets. Because there are contradictory and confusing results in this field, the main research question of this study asks:

RQ1: What is the effect of decreased newspaper competition in a regional market on local news diversity in printed journalism in this region?

In the light of the previous research in this area and based on the previous discussion in this article, three hypotheses about expected relationships are offered.

H1: The decrease of newspaper competition in a region reduces the number of local news articles.

This is consistent with previous research, which generally suggests a positive correlation between the number of media organizations and the number of published news items. News quantity should generally be affected by decreased competition.

H2: The decrease of competition in the newspaper market in a region reduces content diversity in local news reporting.

This hypothesis is partly drawn from previous research suggesting some market structure influence over media content and the previously introduced model for the relationship between news diversity and newspaper market situation.

H3: The decrease of efficiency in the newspaper market in a region reduces content diversity in local news reporting.

This hypothesis is mainly based on the previously presented efficiency-competition model.

Some basic concepts in this reasoning need to be further examined. What is generally meant by media diversity and newspaper competition?

\subsection{Media diversity}

This is undoubtedly one of the most encountered - and hailed - terms in discussions about media policy and the role of media in the most advanced democracies. Media diversity is often said to refer to three basic features of content, namely the wide range of choice for audiences, the many and different opportunities for access for different voices and sources in society and a true or sufficient media reflection of the varied reality of experience in society (McQuail, 2000). When it comes to choice and access it is reasonable to argue that these dimensions of media diversity are better served in a market situation characterized by a larger number of media competitors. In general, newspaper competition should thus encourage media diversity. This concept of reflection, however, needs further discussion. 
Nord, Lars $W$. Newspaper competition and content diversity: a comparison of regional media markets in Sweden.

Theoretically, one single media as by the whole media market could carry out the reflective diversity - in terms of the extent to which existing population preferences are proportionally represented in the media - just as well. The question as to whether such internal media diversity (or intra medium diversity) could replace external media diversity (or inter media diversity) without negative consequences for deliberation and democracy is neither carefully nor fully examined (van Cuilenberg, 2000). As discussed previously, it is reasonable to assume that regional media competition under certain circumstances is encouraging reflective diversity, but on the other hand it sometimes favours mainstream and majority positions in the news in the search for the biggest audience. The latter situation will probably occur more often in markets where newspapers are under severe economic pressures to reduce costs and gain markets share.

\subsection{Newspaper competition}

As contextualized here and in many other studies, newspaper competition is a dichotomous concept. It either exists, or it does not. However, as noted above, the character of the existing newspaper competition in a market can vary from ruinous competition to effective competition.

\section{METHOD}

Data for this study comes from two different quantitative content analyses of Swedish regional newspapers conducted by the Centre for Study of Democracy and Communication. The first study examined the effects of a media merger in the rural area of Ådalen in Northern Sweden, where two rivalry newspaper companies, Nya Norrland and Vasternorrlands Allehanda, vanished from the market in January 2000 and were replaced by a new company, Tidningen Angermanland. The regional market thus transformed from a ruinous competition to a monopoly market as the two former companies showed negative profit margins before the merger. Two random weeks were selected namely from 1 March to 15 March 1999 and from 1 March to 15 March 2000. All local news pages in the three newspapers were examined. In total, 652 articles were analyzed in this study.

The second study examined the effects of a different media merger in an expansive, big city area in Southern Sweden, where two newspapers with well-defined local markets, Helsingborgs Dagblad and Nordvästra Skånes Tidningar, merged. The same company now owns the two papers after a joint venture in January 2002. The regional market thus transformed from an oligopoly market to a monopoly market as the two former firms had shared the market and showed positive profit margins before the merger. Three random weeks were selected namely from 1 May to 22 May 2001 and from 1 May to 22 May 2002 and all local news pages in the two newspapers were examined. In total, 803 articles were analyzed in this study.

Four media content variables are of particular interest in this study, namely issue diversity, actor diversity, political open diversity and political reflective diversity. All variables are used to measure the degree of diversity in local news. All variables are expressed in an "index of diversity" where the actual distribution of articles in the sample is compared to an ideal and equal distribution of political issues, political actors and political parties dominating local news (open diversity). At last, political 
Nord, Lars $W$. Newspaper competition and content diversity: a comparison of regional media markets in Sweden.

parties in local news are compared to party support in latest local elections (reflective diversity). The index can vary between 0 and 1 .

The following formula may be used to measure diversity:

$$
D=1 \frac{\sum_{i=1}^{c}(f u i-f v i)}{2}
$$

In this article the case studies are used to test the above-mentioned hypotheses about news diversity in different media markets. The results presented below should rather be considered as possible indicators of current trends than as systematic research in the field of regional media development. The two case studies therefore mainly serve as pilot studies in this aspect whose purpose is to help further elaboration of theories and methods within this area of research. The final parts of the article returns to these discussions.

\section{RESULTS}

A basic assumption in most theories about news production and news competition is that media companies compete in the news market, where media supply meets audience demand for news, and based on market theory, ideally converge. Accordingly, a decrease in media organizations within the market should lead to less news, partly because of less space for news but also because of a lower priority given to news in a monopoly situation. There are also reasons to believe that one of the economic arguments for media mergers is based on better possibilities to cut costs for news production in a media monopoly situation. The examinations of the two media mergers in Northern and Southern Sweden with respect to this aspect are shown in Table 1.

Table 1. News production and newspaper competition (number of local news articles)

\begin{tabular}{l|cc}
\hline \multicolumn{1}{c|}{ Newspaper } & Old market & \\
\hline Northern Region: & 169 & \\
\hline Nya Norrland (NN) & 231 & $\underline{\underline{252}}$ \\
Västernorrlands Allehanda (VA) & $\underline{400}$ \\
Tidningen Ångermanland (TÅ) & \\
Total & 221 & \\
Southern Region: & 191 & $\underline{391}$ \\
\hline Helsingborgs Dagblad (HD) & $\underline{\underline{412}}$ \\
Nordvästra Skåne Tidningar (NST) & \\
Total &
\end{tabular}

Note: The results are based on quantitative content analyses of two weeks in 1999 and 2000 in the Northern region, and on three weeks in 2001 and 2002 in the Southern region.

The two cases described here differ significantly. In the Northern region two titles were replaced by one new title and in the Southern region the new publishing company decided to keep the titles of the local markets even though the complete news organization was changed and centralized. The structural features of each market probably explain the supply of local news articles under new market conditions. Not surprisingly, one newspaper company produces less news than two. 
Nord, Lars $W$. Newspaper competition and content diversity: a comparison of regional media markets in Sweden.

The same results were presented in another recent study comparing investigative reporting in local news in different local newspaper markets in Sweden (Nygren, 2003). In the study described here, the southern case also shows that a centralized news management decreases local news coverage in general. The monopoly situation leaves the remaining news management with increased power to decide on news production strategies and priorities. In most cases, this should result in less local news coverage, expect for single market considerations where news focus shifts from one part of the market to another. $\mathrm{H} 1$ states that decreased newspaper competition results in less coverage of local news. The hypothesis is supported by the data in table 1.

The same case studies were also studied in order to examine the degree of diversity in local news in different market situations. In both cases the percentage of the dominating issues and dominating actors of each article were considered and data before and after the fusion compared. Basically, the argument here is that decreased competition should decrease diversity in general. The results of changes in local news issue diversity in this study are shown in Table 2.

Table 2. Local news and newspaper competition (index of diversity)

\begin{tabular}{|c|c|c|c|c|c|c|}
\hline \multicolumn{7}{|c|}{ Issue diversity } \\
\hline \multicolumn{7}{|c|}{ Northern region } \\
\hline Newspaper & NN 1999 & VA 1999 & $T A \dot{2} 2000$ & HD 2001 & NST 2001 & HD/NST 2002 \\
\hline Diversity & 0.65 & 0.62 & 0.73 & 0.63 & 0.68 & 0.48 \\
\hline $\mathrm{N}=$ & 169 & 231 & 252 & 221 & 191 & 391 \\
\hline \multicolumn{7}{|c|}{ Actor diversity } \\
\hline Newspaper & NN 1999 & VA 1999 & $T \AA 2000$ & $H D 2001$ & NST 2001 & HD/NST 2002 \\
\hline Diversity & 0.40 & 0.46 & 0.55 & 0.78 & 0.68 & 0.57 \\
\hline $\mathrm{N}=$ & 169 & 231 & 252 & 221 & 191 & 391 \\
\hline
\end{tabular}

Open political diversity

\begin{tabular}{l|lll||lll}
\multicolumn{4}{c}{ Northern region } & \multicolumn{3}{c}{ Southern region } \\
\hline Newspaper & NN 1999 & VA 1999 & TÁ 2000 & HD 2001 & NST 2001 & HD/NST 2002 \\
\hline Diversity & 0.46 & 0.58 & 0.61 & 0.72 & 0.42 & 0.64 \\
\hline $\mathrm{N}=$ & 169 & 231 & 252 & 221 & 191 & 391 \\
\hline
\end{tabular}

Reflective political diversity

\begin{tabular}{l|lll||lll}
\multicolumn{4}{c}{ Northern region } & \multicolumn{3}{c}{ Southern region } \\
\hline Newspaper & NN 1999 & VA 1999 & TA 2000 & HD 2001 & NST 2001 & HD/NST 2002 \\
\hline Diversity & 0.64 & 0.77 & 0.78 & 0.74 & 0.57 & 0.89 \\
\hline $\mathrm{N}=$ & 169 & 231 & 252 & 221 & 191 & 391 \\
\hline
\end{tabular}

The picture of local issues covered by the newspapers before and after the market changes seems to be affected by the new conditions. Especially notable is the dramatically decreased issue diversity in the southern market. In the northern market no such concentration of issues was noticeable in the new monopoly situation. On the contrary, issue diversity actually slightly improved in the new market situation. $\mathrm{H} 2$ states that a decrease in market competition reduces news diversity. The hypothesis is not supported by data reflecting issue diversity in local news. H3 states that a 
Nord, Lars $W$. Newspaper competition and content diversity: a comparison of regional media markets in Sweden.

decrease in market efficiency reduces news diversity. The hypothesis is supported here.

Diversity in news is, however, not only a question about the issues covered by local newspapers. There is also a good reason to look to the actors in the news and see whether there is any diversity between different actors. Diversity in actors is differently affected by monopolization of regional media markets. A negative effect is only obvious in the southern market, where the former oligopoly resulted in better diversity than the former ruinous competition on the northern market. The same pattern appeared as in the comparison of issue diversity. When a ruinous competition was replaced by a media monopoly diversity even increased a bit. $\mathrm{H} 2$ is not supported, while $\mathrm{H} 3$, once again, is supported. The southern market situation changing from oligopoly to monopoly is much more affected in relative figures, even if diversity in actors is still slightly better compared to the northern market.

Diversity is basically a concept closely connected to the vision of the marketplace of political ideas. Different political opinions should in a well-functioning democracy be reflected in media content in a fair and reasonable way. Political diversity in this study was analyzed in two ways. Firstly, open political diversity was analyzed by comparing local news with an ideal and equal distribution of political parties and representations of political parties. Secondly, reflective political diversity was measured by comparing local news with public support for political parties in recent local elections.

Generally, the political diversity results confirm the earlier noticed trends in the study. The ruinous competition region is less affected by less competition in terms of political diversity. Political opinions and ideas seem to be as well reflected, if not better, by the remaining single newspaper. In the southern market, no obvious trends can be observed as both newspapers differ significantly in this aspect in the oligopoly situation. These differences are probably explained by internal factors, as editorial policies and preferences. The rather surprising improvement of reflective political diversity in the southern region could have a political explanation as there were local elections in Sweden in 2002, which may have encouraged more reflective political journalism despite editorial concentration. $\mathrm{H} 2$ is still not supported by data in this study. H3 is slightly supported, but other factors, especially the local political context, seem to be of importance in explaining reflective political diversity.

\section{DISCUSSION}

This study has explored the relationship between newspaper competition in local and regional markets and local news diversity. The findings from the limited content analysis reported here show that market monopolization first of all affects news quantity as the number of local news articles produced decreases significantly. The supply of local news decreases when there are less local media companies on the scene. Based on numbers, local monopolies or more monopolized market conditions give the public less local news and probably less local high quality news. This quantitative approach is in many ways reasonably easy to understand and is widely used in media policy argumentation for both press subsidies and deregulation of broadcast media. This approach, solely based upon the supply side of news production, and supported by both liberals and socialists in modern democracies, could without doubt be described as "the paradigm" of contemporary media policy. 
Nord, Lars $W$. Newspaper competition and content diversity: a comparison of regional media markets in Sweden.

The quantitative and supply side approach is, however impressively implemented in media policies, nevertheless insufficient for a complete understanding how the media market structure actually influences the conditions of local democracy. As shown in the comparisons in this paper the local news diversity sometimes decreases when competition disappears. The main finding here is that reduction in news diversity actually varies with different market changes. Both competition and efficiency in the market seem to be of some importance in explaining the variations. Moreover, some surprising results were noticed. Local news diversity was actually a bit better after the monopolization of the newspaper market in Northern Sweden.

These findings should at least signal some caution when discussing the effects of newspaper competition on local news diversity. The supply of news does not always correlate to the degree of diversity. There are probably other important factors involved (not analyzed here) such as news values, news management, news budgets and owner publicity policies, just to mention a few. This study gives some support to the thought that ruinous competition should be as avoided as ruthless monopoly. However, much more systematic research is of course needed to predict the democratic benefits of possible market situations in between these two extremes. Perhaps, most importantly, the public debate about media concentration would be improved by avoiding the most simplified stereotypes about competitive diversity markets and non-diversity monopolies. Taken together, these findings suggest that the relationship between newspaper market structure and local news diversity is actually more complicated than at first thought.

Finally, the original design of the Swedish case studies introduced here obviously limits the ability to generalise the findings. To get a plausible picture of long-term and permanent effects of media mergers content diversity have to be analyzed during a long period after the market has changed. Future and more systematic research in this field is thus needed to examine the role of newspaper competition in maintaining and strengthening local democracy. 
Nord, Lars $W$. Newspaper competition and content diversity: a comparison of regional media markets in Sweden.

\section{REFERENCES}

Baker, E. (2002): Media, Markets and Democracy, Cambridge: Cambridge University Press.

van Cuilenberg, J. (2000): On Measuring Media Competition and Media Diversity: Concepts, Theories and Methods, In Picard, R. (ed.): Measuring Media Content, Quality and Diversity, Turku: Academy of Finland.

Doyle, Gillian (2002): Media Ownership, London: Sage.

Entman, R. (1989): Democracy without Citizens - Media and the Decay of American Politics, Oxford: Oxford University Press.

Keane, J. (1991): Media and Democracy, London: Polity Press.

Lacy, S. (2000): Commitment of Financial Resources as a Measure of Quality, In Picard, R. (ed.): Measuring Media Content, Quality and Diversity, Turku: Academy of Finland.

Lacy, S., Coulson, D. \& St. Cyr, C. (1999): The Impact of Beat Competition on City Hall Coverage, Journalism \& Mass Communication Quarterly No. 2, 325-340.

Litman, B. \& Bridges, J. (1986): An Economic Analysis of Daily Newspaper Performance, Newspaper Research Journal No.7, 9-26.

McManus, J. (1994): Marketdriven Journalism - let the Citizen Beware? Thousand Oaks: Sage.

McQuail, D. (1992): Media Performance: Mass Communication and the Public Interest, London: Sage.

McQuail, D. (2002): Mass Communication Theory $4^{\text {th }}$ ed., London: Sage.

Meier, W. \& Trappel, J. (1998): Media Concentration: Options for Policy, In McQuail, D \& Siune, K. (eds.): Media Policy - Convergence, Concentration \& Commerce, London: Sage.

Nord, L. (2002): Medieskugga, Stockholm: Atlas.

Nygren, G. (2003): Granskning med förhinder, Sundsvall: Demokratiinstitutet.

Page, B. (1996): Who Deliberates? - Mass media in Modern Democracy, Chicago: The University of Chicago Press.

Picard, R. (2000): Measuring Quality by Journalistic Activity, In Picard, R. (ed.): Measuring Media Content, Quality and Diversity, Turku: Academy of Finland. 